\title{
Investigation into Effectiveness of Questionnaire as a Method of Scientific Research
}

\author{
J. T. Oladeji \\ Department of Mechanical Engineering Ladoke Akintola University of Technology, P.M.B. 4000, Ogbomoso, Nigeria
}

\begin{abstract}
Questionnaires are often used as methods of scientific research and surveys, especially in education and social sciences. This study, therefore investigated the effectiveness of questionnaires as methods of scientific research and survey using the performance of male and female students in engineering drawing at Ladoke Akintola University of Technology, Ogbomoso as a case study.

Two sets of data were obtained. The first was obtained through cross-sectional structured questionnaires, which were administered to 98 students that are made of $28.57 \%$ females and $71.43 \%$ males. The statistical methods used for data obtained consisted of descriptive statistics of frequency counts and chi-square tests. The second set are the secondary data in form of the results or scores for the past five years, which were collected from the examination officers of various departments, through the permission of their heads of departments. Cumulative grade point average (CGPA) of the students was used and the data obtained were analysed using means and standard deviations at $95 \%$ confidence level. Data were further subjected to t-test analyses through the employment of Chi-square tests.

Based on the questionnaire, the results of the study showed that hypothesis that says, there is no significant difference between the performance of male and female students in engineering drawing was rejected as $\mathrm{X}_{2}$ calculated for the hypothesis was greater than $X_{2}$ critical at $95 \%$ confident level, while for the second data, statistics revealed that, there was no significant difference in the overall performance between the male and female students in engineering drawing.

Since the second set of data was the actual performance of the students, the study concluded that, questionnaires as methods of scientific research and survey, sometimes, may not reflect the true position of things and results from such method should not be absolutely relied upon.
\end{abstract}

Keywords Effectiveness, Questionnaire, Gender, Performance

\section{Introduction}

There are many methods of scientific research and investigations. There are many definitions of the world "Research". Opinions seem to differ on the appropriate definition of research as there is no universal or generally accepted definition of the concept[1]. The definition of Research depends on the view and perspective of authors. Different authors define Research in different ways. For example, Nzeribe and Ilogu[2] defined Research as any organized inquiry carried out to provide information for the solution of a problem. However, common features of research are listed below:-

i. Research is a systematic and scientific investigation.

ii. Other words that are synonymous to research include analysis, investigation, inquiry, study etc

iii. Research is a tool for solving different social problems.

* Corresponding author:

jtoladeji@gmail.com (J.T. Oladeji)

Published online at http://journal.sapub.org/edu

Copyright (C) 2012 Scientific \& Academic Publishing. All Rights Reserved iv. Research is the formal application of scientific method towards finding solution to a problem.

There are many advantages derivable from carrying out research. Some of them are:-

i. Research can aid discovery of relationships that exist among the world in which we live.

ii. Research can build individual student's ability to conduct and report supervised engineering design/fabrication, scientific investigation or study.

iii. Research uncovers useful knowledge for future practical application

iv. It is also a vital problem-solving tool for practising engineers, technicians and scientists.

There are many ways by which research can be classified. Generally, the following types of research are worthy of mentioning:

i) Applied Research- This type of research is designed to solve specific problems. Applied research can be further sub-divided into 3 main types:

a) Development Research- This is also known as Technical Research. It makes inputs concerning the design of instrument and application of materials.

b) Case Study-A case study is a detailed analysis of the 
developmental changes of a single person, institution, organisation, event or programme. The sample for case study is usually much smaller than that of survey research. Intensive evaluation and analysis of data are necessary to generate valid data.

c) Survey- This is a research method that describes a given state of affairs at a particular time. The method uses questionnaires, interviews and observations for collection of data from a given population based on appropriate sampling techniques.

Questionnaire, according to Macmillan English dictionary can be defined as a set of questions that a lot of people are asked as a way of getting information about what people think or do generally. Sometimes, it may be in form of open ended questions or in form of questions that require either yes or no or short answers. This method of scientific research is very popular and most often used in education and social sciences.

The main objective of this study was to investigate the effectiveness or otherwise of administration of questionnaire as a method of scientific research. This was achieved by comparing the results obtained through administration of questionnaire and the results obtained from the statistical analysis of results of actual performance of male and female students in engineering drawing at Ladoke Akintola University of Technology, Ogbomoso. The goal was to ascertain whether or not biological differences necessarily determine what males and females are able to do in engineering drawing.

\section{Materials and Methods}

This study was conducted among the engineering students of Ladoke Akintola University of Technology, Ogbomoso (LAUTECH). LAUTECH is located in Ogbomoso and was established in 1990. The university was jointly owned by Oyo and Osun States in the south-west geo-political zone of the country and was the state best university in Nigeria for four years consecutively. The university has a population of about twenty six thousand and it is heterogeneously inhabited by many Nigerian tribes namely: Yoruba, Ibo, Hausa, and other minority tribes. The university has six faculties and the main religions practised within the university are Christianity and Islam.

For the purposes of this study, two sets of data were obtained. The first set of data was obtained through cross-sectional structured questionnaires, which were administered to 98 students that are made of $28.57 \%$ females and $71.43 \%$ males. The hypothesis put forward was that there will be no significant difference in the performance in engineering drawing between the male and female engineering students of Ladoke Akintola University of Technology, Ogbomoso. Data obtained were subjected to statistical analysis and the statistical methods used consisted of descriptive statistics of frequency counts and chi-square tests. The Chi-square test was used to test the hypotheses formu- lated with p-value of 0.05 or less considered statistically significant. For the second set of data, secondary data in form of the results or scores for the past five years were collected from the examination officers of various departments through the permission of their heads of departments. Data were analysed using means and standard deviations at $95 \%$ confidence level. Data were further subjected to t-test analyses through the employment of Chi-square tests. The method was used because it is considered to be the most appropriate method of comparing means of two groups, which are subjected to the same conditions[3; 4]. All the statistical analyses were performed on a micro-computer using SPSS 11.0 (Statistical Package for Social Science, 2002). The outcome of the two sets of the results was compared and appropriate deductions were made.

\section{Results and Discussions}

The results of response from administration of questionnaire are presented in Tables 1 and 2, while Table 3 represented results of extracts of chi-square test on the postulated hypothesis.

Table 1. Sex of the Respondents

\begin{tabular}{|c|c|c|}
\hline Sex & Number of Respondents & Percentage \\
\hline Female & 28 & $28.57 \%$ \\
\hline Male & 70 & 71.43 \\
\hline
\end{tabular}

Table 2. Male perform better than Female Students

\begin{tabular}{|c|c|c|c|}
\hline \multirow{2}{*}{ Response } & \multicolumn{3}{|c|}{ Number of Respondents } \\
\cline { 2 - 4 } & Strongly Agreed & Agreed & Undecided \\
\hline Yes & 34 & 40 & 5 \\
\hline No & 2 & 7 & 5 \\
\hline
\end{tabular}

Table 3. Extracts of Chi-Square Tests on Postulated Hypothesis

\begin{tabular}{|c|c|c|c|c|c|}
\hline Hypothesis & $\begin{array}{c}\mathrm{X}_{2} \\
\text { Calculated }\end{array}$ & $\begin{array}{c}\mathrm{X}_{2} \\
\text { Critical }\end{array}$ & Df & $\begin{array}{c}\mathrm{P} \\
\text { value }\end{array}$ & Remarks \\
\hline $\mathrm{I}$ & 12.091 & 0.103 & 2 & 0.002 & $\begin{array}{c}\text { There is signifi- } \\
\text { cant difference }\end{array}$ \\
\hline
\end{tabular}

For the second set of data, the results of computed mean scores for a period of 5 years were presented in Table 4 , while Table 5 shows extracts from the ANOVA test.

From the Table 3, it can be seen that the hypothesis put forward was rejected as $\mathrm{X}_{2}$ calculated for the hypothesis was greater than $X_{2}$ critical at $95 \%$ confidence level. The implication of this is that, the reverse of the null hypothesis is the case, i.e. there is significant difference in the performance between the male and female students in engineering drawing.

Table 4. Computed mean scores of students for 5 years

\begin{tabular}{|c|c|c|}
\hline \multirow{2}{*}{ Academic Year } & \multicolumn{2}{|c|}{ Students' Performance } \\
\cline { 2 - 3 } & Female & Male \\
\cline { 2 - 3 } & $\begin{array}{c}\text { Mean score } \\
\text { of 10 students }\end{array}$ & $\begin{array}{c}\text { Mean score } \\
\text { of 20 students }\end{array}$ \\
\hline $2005 / 2006$ & 2.875 & 2.344 \\
$2006 / 2007$ & 2.687 & 3.125 \\
$2007 / 2008$ & 2.50 & 2.844 \\
$2008 / 2009$ & 2.25 & 3.186 \\
$2009 / 2010$ & 3.00 & 3.313 \\
\hline
\end{tabular}


Table 5. Anova Test

\begin{tabular}{|c|c|c|c|c|c|c|}
\hline $\begin{array}{c}\text { ANOV } \\
\text { A }\end{array}$ & & & & & & \\
\hline $\begin{array}{c}\text { Source } \\
\text { of } \\
\text { Varia- } \\
\text { tion }\end{array}$ & SS & $\begin{array}{l}\text { D } \\
\mathrm{f}\end{array}$ & MS & $\mathrm{F}$ & $P$-value & $\begin{array}{c}\mathrm{F} \\
\text { crit }\end{array}$ \\
\hline Years & $\begin{array}{c}0.7871 \\
09\end{array}$ & 4 & $\begin{array}{c}0.1967 \\
77\end{array}$ & $\begin{array}{c}1.2445 \\
95\end{array}$ & $\begin{array}{c}0.34396 \\
2\end{array}$ & $\begin{array}{c}3.2591 \\
6\end{array}$ \\
\hline $\begin{array}{c}\text { Gender/ } \\
\text { course }\end{array}$ & $\begin{array}{c}0.5031 \\
25\end{array}$ & 3 & $\begin{array}{c}0.1677 \\
08\end{array}$ & $\begin{array}{c}1.0607 \\
37\end{array}$ & $\begin{array}{c}0.40191 \\
2\end{array}$ & 3.4903 \\
\hline Error & $\begin{array}{c}1.8972 \\
66\end{array}$ & $\begin{array}{l}1 \\
2\end{array}$ & $\begin{array}{c}0.1581 \\
05\end{array}$ & & & \\
\hline Total & 3.1875 & $\begin{array}{l}1 \\
9\end{array}$ & & & & \\
\hline
\end{tabular}

From Table 5, it can be seen that the results of t-tests in the course examined, there is no significant difference between the performance of female and male students in the engineering course examined as $t$ calculated at both one tail and two tails are less than t-critical for the course examined at $5 \%$ significant level.

It can be seen that the results obtained from the two methods of investigation contradicted one another, and since the results from the administration were the opinions of the respondents, the results obtained from actual marks of the students are hereby declared authentic. This result seems to agree with the reports of Buckland and Joyce[5] and Yahaya[6] that gender analysis of performance is not on biological differences. This study also agreed with the work of Adeyinka[7], where the researcher concluded that, there was no significant difference in the overall performance between the male and female students in the agricultural science and biology in Kwara State College of Education, Oro in the 2002 set. The works of Aolat[8], Oladeji et al[9] and Oladeji and Sangotayo[10] also gave similar results. However, the results of this study contradicted the views of some teachers, who believed that males are academically superior to females in some developing countries of Africa as expressed by Adhimabi and Heneveld[11]. The result of this work seems to contradict the outcome of Oladeji et al[12], where through the administration of questionnaires, their result claimed that there was significant difference between the performance of male and female students in engineering drawing. Furthermore, the result of Chi-test for the hypothesis in question might as well show the subjectivity of questionnaire as a method of research, taking into cognisance that more than $71 \%$ of the respondents were males and the possibility of being biased could not be ruled out.

\section{Conclusions}

From the results obtained from this study, the following conclusions can be drawn:-

i. Questionnaires as methods of scientific research and survey, sometimes, may not reflect the true position of things and results from such method should not be absolutely relied upon.

ii. The results obtained from administration of questionnaires should not be generalized, after all, if such investiga- tion is conducted elsewhere, it may produce another result entirely.

iii. The gender of a student does not have anything to do with his/her academic performance.

iv. Male students are not academically superior to their female students' counterparts.

\section{REFERENCES}

[1] Oladeji, J. T., 2011a. Procedures in Writing A Final Year Project Report in Tertiary Institutions Nazirite Communications Limited, Lagos

[2] Nzeribe, C.G.O., and Ilogu, G.C., 1996, Fundamentals of Research Methods, Optimal International Limited, Enugu

[3] Ogunleye, O.O., 2009, "Optimizing Raw Materials Formulation for Flexible Polyurethane Foam Production” An Unpublished Ph.D Thesis in the Department of Industrial and Production Engineering. Faculty of Technology, University of Ibadan, Ibadan

[4] Oladeji, J.T., 2011b "The Effects of Some Processing Parameters on Physical and Combustion Characteristics of Corncob Briquettes" Unpublished Ph.D Thesis in the Department of Mechanical Engineering Faculty of Engineering and Technology, Ladoke Akintola University of Technology, Ogbomoso

[5] Buckland, L. and Joyce, H., 1996, "Gender Analysis in Agricultural Production, International Institute for Tropical Agriculture (IITA), Research Guide 58, Ibadan, pp 5-14

[6] Yahaya, A.A., 2005. “Gender Analysis of Students' Performance in Agricultural Education- A Case Study of College of Education, Oro" Oro Journal of Education and Technological Studies, Vol. 3 (1) pp 34-37

[7] Adeyinka, C.O., 2010, "A Comparative Study of Male and Female Students in Agricultural Science and Biology in Kwara State College of Education, Ilorin" Proceedings of the 2nd National Engineering Conference, Federal Polytechnic, Offa, held between 13th -15th July pp 111-113

[8] Aolat, A., 2010, "Comparative Study of Performance of Male and Female students in NECO and WASC Examinations in Agricultural Science in Some Selected Secondary Schools in Irepodun LGA, An Unpublished B.Ed. Project, College of Education, Oro, Kwara State

[9] Oladeji, J.T., Sangotayo, E.O., and Adebiyi, K.A., 2011a, "Determinants of Performance of Students of Ladoke Akintola University of Technology, Ogbomoso in Engineering Drawing"

[10] Oladeji, J.T. and Sangotayo, E.O., 2011, “A Comparative Study of Performance of Mechanical Engineering Students in Selected Basic Engineering Courses at Ladoke Akintola University of Technology, Ogbomoso" Academia Arena 3(4) pp 57-60

[11] Adhimabi, O., and Heneveld, W., 1995, Girls and Schools in Sub-Sahara Africa, Tomio, Nairobi, pp 33- 36

[12] Oladeji, J.T., Sangotayo, E.O., and Adebiyi, K.A., 2011b, “A Comparative Study of Performance of Male and Female Students in Engineering Drawing at Ladoke Akintola University of Technology, Ogbomoso" Researcher 3(5) pp 9-12 